\title{
A newly discovered manuscript of
}

\section{pseudo-Aristotle's Physiognomonica}

\author{
Lisa Devriese
}

\section{Introduction}

The ongoing cataloguing project 'Minor Manuscript Collections' at the Manuscript Research Centre (Handschriftenzentrum) of the university library of Leipzig explores and catalogues minor medieval and early modern manuscript holdings in East Germany. Since these isolated manuscript collections are scarcely known and their content not yet catalogued, new source material is continually made available to modern scholars. ${ }^{1}$ One of the eleven institutions that are systematically catalogued within the framework of this project is the Municipal Archive (Stadtarchiv) of Mühlhausen in Thuringia (Germany). The manuscript with shelf mark 60/13 is a philosophical volume that contains, among other treatises, the Latin medieval translation of the pseudo-Aristotelian Physiognomonica. ${ }^{2}$

The discovery of a new manuscript containing the medieval Latin translation of the Physiognomonica is of interest for this article. The critical edition of the Physiognomonica, based on a reading of all the existing 128 manuscripts, was published in 2019 in the Aristoteles Latinus series, but the existence of this manuscript of Mühlhausen was unknown at that time. ${ }^{3}$ The goal of this article, therefore, is to focus on this newly discovered manuscript: first, to complete the information provided in the printed Aristoteles Latinus edition and assess the value

\footnotetext{
1 "Cataloguing of Medieval Manuscripts in Minor Collections in East Germany," accessed May 3, 2021, https://www.ub.uni-leipzig.de/en/research-library/projects/projects-by-date/cataloguing-small-collections-ofmedieval-manuscripts-in-eastern-germany/.

${ }^{2}$ I am grateful to Matthias Eifler, who works on this project, to have informed me on the discovery of this new manuscript containing the Physiognomonica (friendly email conversation starting September 10, 2020).

${ }^{3}$ Aristoteles, Physiognomonica. Translatio Bartholomaei de Messana, Aristoteles Latinus 19, ed. Lisa Devriese (Turnhout, 2019).
} 
of this manuscript for the reconstruction of the Latin translation, and secondly, to discuss the many marginal annotations in this manuscript. These annotations may in turn provide some information on the dissemination of this pseudo-Aristotelian treatise in the Middle Ages.

The pseudo-Aristotelian Physiognomonica deals with physiognomy, a discipline that searches for a link between a person's external physical traits and his/her character traits. Throughout Antiquity and the Middle Ages, the treatise was attributed to Aristotle and was included in the Corpus Aristotelicum; hence the reason why this text was also incorporated in the Aristoteles Latinus project. In the second half of the thirteenth century, amid a wider movement that translated the Aristotelian treatises into Latin, the Physiognomonica was translated from Greek into Latin by Bartholomew of Messina, who was active at the court of King Manfred of Sicily (1258-1266). Of this Latin translation, 129 manuscripts have survived, including the newly discovered Mühlhausen manuscript. ${ }^{4}$

\section{Description of the manuscript}

Manuscript Mühlhausen, Stadtarchiv 60/13 is a philosophical composite manuscript and consists of at least four fascicles [I-IV] created by different scribes at slightly different times. ${ }^{5}$

\footnotetext{
${ }^{4}$ More information on the discipline of medieval physiognomy, and on the translation movement and the translator Bartholomew of Messina, can be found in: Jole Agrimi, Ingeniosa scientia nature: Studi sulla fisiognomica medievale (Florence, 2002); Jozef Brams, La riscoperta di Aristotele in occidente (Milan, 2003); Joseph Ziegler, "Philosophers and Physicians on the Scientific Validity of Latin Physiognomy, 1200-1500," Early Science and Medicine 12 (2007): 285-312; Charles Burnett, "Translation and Transmission of Greek and Islamic Science to Latin Christendom," in The Cambridge History of Science: Medieval Science, ed. David C. Lindberg and Michael H. Shank (Cambridge [UK], 2013), 341-364; Marke Ahonen, "Medieval and Early Modern Physiognomy," in Sourcebook for the History of the Philosophy of Mind, ed. Simo Knuttila and Juha Sihvola (Dordrecht, 2014), 633-637; Pieter De Leemans, ed., Translating at the Court. Bartholomew of Messina and the Cultural Life at the Court of Manfred, King of Sicily, Mediaevalia Lovaniensia 45 (Leuven, 2014); Lisa Devriese, "The Body as a Mirror of the Soul. An Inquiry into the Reception of pseudo-Aristotle's Physiognomonica in the Middle Ages" (PhD diss., University of Leuven, 2018). The critical edition of the Latin translation is published in Aristoteles, Physiognomonica, ed. Devriese.

${ }^{5}$ Matthias Eifler has provided me with a detailed description of this manuscript regarding its content, binding, codicology, and history. The information in this section relies on this description, which will soon be made available on the German online manuscript catalogue Manuscripta Mediaevalia: http://www.manuscriptamediaevalia.de/dokumente/html/obj31633199.
} 
The manuscript contains the following treatises: 1. Johannes Buridanus, Expositio in duodecim libros Metaphysicorum Aristotelis, fols. 1ra-43vb [I]; 2. Commentarius in Boethii De consolatione philosophiae, fols. 44ra-114v [II]; 3. Pseudo-Aristoteles, De pomo et morte, fols. 115r-121r [II]; 4. Aristoteles, Ethica Nicomachea cum glossa (translatio Roberti Grosseteste Lincolniensis), fols. 122r-144r [III]; 5. Schemata, fol. 144v [III]; 6. Arthurinus Parisiensis (?), Summa Ethicae abbreviata, cum expositione, fols. 145ra-169vb [III]; 7. Pseudo-Aristoteles, Oeconomica, lib. I et III (translatio Durandi de Alvernia), cum commento, fols. 170r-177v [IV]; 8. Pseudo-Aristoteles, Physiognomonica, cum commento, fols. 178r-182v [IV].

The Latin Physiognomonica is the last treatise contained in this manuscript and is, together with the Latin translation of pseudo-Aristotle's Oeconomica, part of the fourth fascicle [IV]. This fourth fascicle is the oldest: according to the watermarks, it was created around 1420, while the other fascicles were created between 1425 and 1432. The four fascicles were probably brought to the Dominican monastery in Mühlhausen by Hermann von Thalheim, who was prior around 1441. He may have acquired the four fascicles during his Artes-studies in Erfurt.

\section{Value of the manuscript for the critical edition}

The most important issue that must be addressed first, is to assess whether this new witness of the Physiognomonica has any value for the reconstruction of the Latin translation made by Bartholomew of Messina. Does the text contain exceptional readings, and does it challenge the text published in the edition, or does it transmit a text of an average quality? A thorough examination of this manuscript shows that the latter is true. In order to demonstrate this, I will discuss the codicological stemma and the position of the witness in it.

One can quickly and easily form an idea of which group the Mühlhausen manuscript belongs to, because the critical apparatus of the edition of the Physiognomonica works with groups of 
manuscripts, rather than with all the individual manuscripts. ${ }^{6}$ The groups of manuscripts each reflect the different stages in which the Physiognomonica was copied and disseminated during the Middle Ages. The entire manuscript tradition of the Latin Physiognomonica ultimately consists of two parts. On the one hand, the Italian independent tradition, which consists of only one extant manuscript, offers a text of a superior quality. On the other hand, the Parisian tradition, which has its origin at the medieval university of Paris, consists of several subgroups $\left(\mathbf{P}^{\mathbf{1 - 4}}\right)$, each offering a version that is inferior to the previous subgroup. The majority of the extant manuscripts are copies from the second Parisian group $\mathbf{P}^{\mathbf{2}}{ }^{7}$

The readings mentioned in the critical apparatus - based on the groups - are sufficient to position the newly discovered manuscript in the stemma codicum. Because each of the groups has its own set of common mistakes, we immediately notice that the manuscript of Mühlhausen belongs to group $\mathbf{P}^{\mathbf{2}}$ and more specifically $\mathbf{P}^{\mathbf{2} a}$. Therefore, we can safely state that the new manuscript does not play a role in the reconstruction of the original translation, which was based on the Italian independent tradition and the first Parisian group $\mathbf{P}^{\mathbf{1}}{ }^{8}$

However, the Mühlhausen manuscript may still display a close connection to one of the other extant manuscripts, or to a number of manuscripts, which cannot be deduced from the critical apparatus. Therefore, when examining the manuscript, I have consulted my own unpublished collations of all the individual manuscripts in order to search for a possible close link. In what follows, I mention a few examples, but not to demonstrate that the Mühlhausen manuscript belongs to $\mathbf{P}^{\mathbf{2} a}$; rather, some examples of atypical readings that are shared with only a few of the other 128 manuscripts. The numbers refer to the Aristoteles Latinus numbers, which can be

\footnotetext{
${ }^{6}$ Because of the high number of manuscripts, mentioning each variant of the individual manuscripts would have burdened the critical apparatus, and would not have provided useful information for the reconstruction of the translation.

${ }^{7}$ A more elaborate discussion of the Latin manuscript tradition and a diagrammatical representation of the stemma codicum can be found in Aristoteles, Physiognomonica, ed. Devriese, xxvii-1xii.

${ }^{8}$ For a discussion of the editorial principles and of the constitution of the text, see ibid., xci-xcvii.
} 
consulted in the conspectus codicum of the edition. ${ }^{9}$ The letter ' $\mathrm{M}$ ' stands for the Mühlhausen manuscript.

\author{
(first pecia) r. 6 fit circa] autem circa 937, 949, 1053, M | r. 7 et] in 308, 937, M | r. 9 plurimarum] \\ diversarum 937, M | r. 10 vel generatum] et generatum 937, 1151, M | r. 12 id est animalis] specie \\ 937, 964, 1324, M | r. 15 autem equos] enim et equos 937, M | r. 16 erit] tr. post utique 937, M | \\ r. 19 quidem] om. 1374, M | r. 22 habenti] habentibus 937, M | r. 28 mos] disposito 964, M : \\ dispositus 1324 | r. 29 coeunti] om. 976, M | r. 241 igitur] ergo 937, M | r. 248 solvitur] dissolvitur \\ 844, 890, 937, Mon., M | r. 248 a mania] ab inania 937, 906A, 1324, M \\ (second pecia) r. 442 habent $^{2}$ ] tr. post forte $738,937,1374, \mathrm{M} \mid$ r. 446 rotundum] add. fronti M : \\ add. frontis $890,949,1537,1755$ | r. 447 habent] add. nasum 937, M | r. 451 qui faciem] \\ quicumque autem habent faciem 937, M | r. 453 valde parvam] inv. 42, 87, 135, 937, 949, 1324, M \\ | r. 453 pusillanimi] pusillanimes 817, 937, M | r. 581 in alio] et aliud 42, 87, 135, 937, 1324, M | \\ r. 586 enim motu] inv. 812, M | r. 586 existente] post motu 812, 890, 906A, 937, M
}

Considering this list of examples, the Mühlhausen manuscript clearly shares significant common errors with the text of A.L. 937, which is manuscript Wolfenbüttel, Herzog August Bibliothek, Cod. Guelf. 17.21 Aug. $4^{\circ}$ (a. 1419-1420). ${ }^{10}$ However, notwithstanding the many

\footnotetext{
${ }^{9}$ Aristoteles, Physiognomonica, ed. Devriese, xviii-xxvii. These are the numbers of the Aristoteles Latinus codices: Georges Lacombe et al., Aristoteles Latinus. Codices. Pars prior (Rome, 1939), Lorenzo Minio-Paluello, Aristoteles Latinus. Codices. Pars posterior (Cambridge [UK], 1955), digitized at https://hiw.kuleuven.be/dwmc/al/DALE.

10 This manuscript is discussed in Otto von Heinemann, Die Augusteischen Handschriften 4 (Frankfurt am Main, 1966), 225-226 number 3112, also available online, accessed May 3, 2021 at http://diglib.hab.de/wdb.php?dir=drucke/f4f-539-7\&pointer=234. The colophon on fol. 103v informs us on the date of the Physiognomonica: "Et sic finitur phisionomia Aristotelis anno 1419 in purificatione beatissime Marie virginis, cuius humilitas Elizabeth vetule servire non indignum sed beatitudinis esse tytulum reputavit." Another part of the manuscript was written in 1420 (see the colophon on fol. 71v). On fol. 36r, the name of Johannes Braxator is mentioned, who was possibly a former possessor ("Johannes Braxator civis in Magdeborch"). This manuscript contains the following treatises: 1. Parva philosophica necnon naturalia, fols. 1r-35r; 2 . Excerpta tabularum regis Alphonisi magnifici, fols. $37 \mathrm{r}-52 \mathrm{v}$; 3. Tractatus de ordinatione corporum celestium, fols. $52 \mathrm{v}-$ 55v; 4. Tractatus de lineis, angulis et figuris, fols. 56r-58r; 5. Quaedam de motibus planetarum, fols. 58v-59r; 6. Enigmata et alia jocosa, fols. 60r-60v, 85r-85v; 7. Compositio et utilitates horoluminis (sic), fols. 61r-71v; 8. Compositio horologii, fols. 72r-73v; 9. Algorismus de minuciis, fols. 74r-85r; 10. Aristotelis Physiognomia, fols. 86r-103v; 11. Auctoritates Aristotelis, fols. 104r-104v; 12. Tractatus de mensurationibus, fols. 105r-106r; 13. Tractatus de capacitate vasis, fols. $106 \mathrm{v}-108 \mathrm{v} ; 14$. Auctoritates metaphysicae Aristotelis et aliorum philosophorum, fols. 109r-150r; 15. Petri de Uboldo de Perusia tractatus de canonica parochiali, fols. 151r203v; 16. Expositiones lectionum vigiliarum, fols. 204r-215v; 17. Versus de passione Domini, fol. $215 \mathrm{v} ; 18$.
} 
shared readings with this manuscript, the two manuscripts are not direct descendants from one another. They differ on several points, as can be seen from the list of examples. Moreover, we also detect omissions in one manuscript, while the passage is present in the other manuscript. These additions or omissions clearly show that one manuscript is not a direct descendant of the other manuscript.

Examples of words that are missing in Mühlhausen (M), but present in Wolfenbüttel. Therefore,

Wolfenbüttel is not a direct copy of Mühlhausen:

r. 576-577 qui autem - autem] om. M

r. 582-583 nichil - frigiditatem] om. M

Example of words that are missing in Wolfenbüttel (937), but present in Mühlhausen. Therefore,

Mühlhausen is not a direct copy of Wolfenbüttel:

r. 21-22 alii autem in talibus - putabant] om. 937

Moreover, we find no traces of corrections by a second hand in any of these manuscripts. The Mühlhausen manuscript and the Wolfenbüttel manuscript therefore seem to be two separate descendants from a common origin, a lost ancestor.

\section{Interlinear and marginal annotations}

Even though manuscript Mühlhausen, Stadtarchiv, 60/13 has no real value for the reconstruction of the original Latin translation made by Bartholomew of Messina, it remains interesting for another reason. In this section, I will focus on the interlinear and marginal annotations that can be found in this manuscript.

Computus Cirobraxis versibus conscriptus, fols. 216r-238v. Note that, apart from the Physiognomonica, none of the other texts appear in the Mühlhausen manuscript. 
A previous study on the marginal annotations in the manuscripts containing the Latin Physiognomonica showed that 45 of them had marginal annotations, greatly varying in length and number of notes (14 of these 45 contained only one small note). ${ }^{11}$ Discovering a manuscript such as the Mühlhausen one, which contains many marginal and interlinear notes (which actually brings the number to 46 ), is therefore not exceptional, but still very interesting. ${ }^{12}$

The notes are not independent scattered postils, but together form a more or less continuous commentary. ${ }^{13}$ The content of the marginalia is in agreement with one of the conclusions from the previous research on the marginal annotations in the Physiognomonica manuscripts. We notice that an explanation is sought for most of the physiognomic signs mentioned in the pseudo-Aristotelian source text. By using medical concepts, such as complexion and humoral theory, the annotators offer a causal explanation for the physiognomic signs, and at the same time give a theoretical foundation for the discipline of physiognomy. E.g., fol. 179r: "Ratio est quia ista pilositas circa ventrem signum est superhabundatis caloris in pulmone."14

In a few of the other manuscripts containing the Latin Physiognomonica, a link could be found between the marginal notes and the medieval commentary tradition on the Physiognomonica; a verbatim similarity between the marginalia could not be found. Annotators cited not only the older authoritative treatises on physiognomy, but also the medieval commentary by William of Aragon (who wrote his commentary between the end of the

\footnotetext{
${ }^{11}$ Lisa Devriese, "Physiognomy in Context: Marginal Annotations in the Manuscripts of the Physiognomonica," Recherches de Théologie et Philosophie Médiévales 84/1 (2017): 107-141 at 109. One manuscript contains the text of the Physiognomonica twice, which is why 129 manuscripts are mentioned in the article.

${ }^{12}$ The margins at the top, bottom and on the sides are full of texts; only on the three last folios does the number of marginal notes decrease. This is consistent with what was observed in the other manuscripts: there are more annotations at the beginning of the text than at the end; see ibid., 116.

${ }^{13}$ By using lemmata and commenting on it, the passage in question is worded differently, and given more structure and context (e.g., fol. 178r: "In tertia particula primo ponit tertium modum phisionomandi antiquorum, id est quod alii phisionomes dicebant quod animalia..."). However, the lemmata themselves are usually missing - we only notice a blank space.

${ }^{14}$ Devriese, "Physiognomy," 117-121.
} 
thirteenth and beginning of the fourteenth century) seemed to function as a source. ${ }^{15}$ The link between the marginalia and the commentators also became apparent in the fact that both asked the same questions, which could point to the possibility that marginal notes and commentaries originated in the same milieu. ${ }^{16}$

The new Mühlhausen manuscript was examined in order to find a possible link with other marginalia or with medieval commentaries on the Physiognomonica.${ }^{17}$ The result is remarkable: not only for the main text did the Mühlhausen manuscript bear great similarities with manuscript Wolfenbüttel, Herzog August Bibliothek, Cod. Guelf. 17.21 Aug. $4^{\circ}$. They are also very closely related regarding their annotations, both interlinear and marginal.

\section{Interlinear similarities}

The interlinear glosses in the Mühlhausen and Wolfenbüttel manuscript are almost identical: the majority of glosses is shared by the two manuscripts. Some additions, however, are present in only one manuscript, and vice versa. Generally, Wolfenbüttel has more interlinear notes: while Mühlhausen relatively quickly stops adding interlinear notes, Wolfenbüttel continues to do so until the end of the text. I mention a few examples of shared interlinear notes of the first lines of the text:

\footnotetext{
r. 4 egritudinibus] s.l. magnis | r. 5 mutate] s.l. mote | r. 7 timores] s.l. enim (om. 937) que sunt passiones anime | r. 8 conspiciet] s.l. videbit | r. 11 alterius animalis] s.l. enim (om. 937) a sua specie | r. 17 progenerati] s.l. antiqui | r. 17 phisionomes] s.l. id est (om. 937) habentes artem phisionomandi
}

\footnotetext{
${ }^{15}$ An edition of this commentary is made by Paula Val Naval, "Estudio, Edición Crítica, Traducción y Comentario de la Summa supra phisonomiam de Guillermo de Aragón (c. 1300)" (PhD diss., Universidad de Zaragoza, 2006). ${ }^{16}$ Devriese, "Physiognomy," 135-138.

17 For a list of medieval commentaries on the Latin Physiognomonica, see Lisa Devriese, "An Inventory of Medieval Commentaries on Pseudo-Aristotle's Physiognomonica," Bulletin de Philosophie Médiévale 59 (2018).
} 
Such a striking similarity in interlinear annotations is very exceptional in the Physiognomonica tradition and does not occur with any of the other 128 extant manuscripts.

\section{Marginal similarities}

As far as the marginal annotations are concerned, this is for the Physiognomonica tradition also the first example we find of two manuscripts with almost identical notes. The marginalia in the other manuscripts do offer a similar content (e.g., giving a similar explanation for several physiognomic signs), but encountering verbal similarity and the same arguments is very exceptional.

An example of a marginal note, in which the differences are underlined:

\begin{tabular}{|c|c|}
\hline Mühlhausen: & Wolfenbüttel: \\
\hline $\begin{array}{l}\text { Tunc recapitulat ibi ‘Animalium', quia ita dicit } \\
\text { primo: ex illis que dicta sunt superius in precedenti } \\
\text { capitulo patet convenientia masculine et femine } \\
\text { forme. Ex qua convenientia faciliter aliquis potest } \\
\text { colligere qualiter alia animalia participant inter se. Et } \\
\text { subdit quecumque voluerit phisionomare, debet } \\
\text { conspicere omnia quecumque dicetur in electione } \\
\text { signorum ipsorum animalium. Et statim ipse }\end{array}$ & $\begin{array}{l}\text { (fol. 97r) Hic primo dat dispositiones que sunt circa } \\
\text { animam istius animalis; unde dictum est qualis est } \\
\text { dispositio corporis ipsius pardalis, sed in hiis } \\
\text { etcetera, quia dicit primo quod illud animal est } \\
\text { animal parvisitum, illiberale et dolosum. Et ista } \\
\text { dependent ab anima, et non ex corpore, ubi 'Pardalis } \\
\text { etcetera', sed libris animalium etcetera. } \\
\text { 'Animalium autem'. Epilogat philosophus, quia dicit } \\
\text { primo: ex illis que dicta sunt superius in precedenti } \\
\text { capitulo patet convenientia masculine et femine } \\
\text { forme. Ex qua convenientia faciliter aliquis potest } \\
\text { colligere qualiter alia animalia participant inter se. Et } \\
\text { quod quecumque voluerit phisionomare, debet } \\
\text { conspicere omnia que dicetur in electione signorum } \\
\text { ipsorum animalium. Et statim phisionomisat in }\end{array}$ \\
\hline
\end{tabular}




\begin{tabular}{|l|l|}
\hline phisionomisat in capitulum sequens, volens quod ex & capitulum sequens, ibi 'Electio', volens quod ex illis \\
illis signis in sequentibus recitandis procedit & signis in sequentibus recitandis procedit diversitas \\
diversitas ipsorum hominum et qualiter phisionomon & ipsorum hominum et qualiter phisionomon ponit \\
ponit diversitatem ex illis concludere, scilicet ex & diversitatem ex illis concludere, scilicet ex \\
diversitate dispositionis corporis diversitatem & dispositionis corporis diversitate diversitatem \\
quantum animorum. & quantum animorum, etcetera. \\
\hline
\end{tabular}

While almost all marginal annotations in the Mühlhausen manuscript are to be found in the Wolfenbüttel manuscript, the opposite is not true: the latter has many more annotations. ${ }^{18}$ It is not clear, however, why Mühlhausen copies certain passages, while others are left out: it does happen that Mühlhausen starts a marginal comment which is actually in the middle of a paragraph in Wolfenbüttel. Lack of space could be the reason: the Mühlhausen margins are full, although the number of notes is only half of what can be found in Wolfenbuittel, which has wider margins. Furthermore, some parts of the marginal commentaries are not placed next to the corresponding main text due to this lack of space.

It is difficult to assess the exact relationship between the two manuscripts, because we only have two manuscripts. The fact that Mühlhausen offers almost no new comments or notes compared to Wolfenbüttel suggests that Mühlhausen may have been copied from Wolfenbüttel. The original additions of Mühlhausen, such as some smaller notes, or the different first sentences of each lemma, could be attributed to the copyist or scholar himself. Nevertheless, the order in which some marginal notes and comments appear in both manuscripts could suggest that the manuscripts are not copies from one another, but rather copies from a lost common source. A first example where the order of the marginalia does not correspond between the two

\footnotetext{
${ }^{18}$ Some folios even contain a continuous commentary without the main text of the Physiognomonica. Since this happens while the other side of the folio does mention the main text, indicates that the pages with commentary were not inserted at a later stage, but were written simultaneously with the main text (and in the same hand). The scribe of the Wolfenbüttel manuscript anticipated the inclusion of annotations and commentary, while no such claim can be made with certainty about the scribe of the Mühlhausen manuscript, given the different mise en page.
} 
manuscripts is the following: Wolfenbüttel (fol. 88r) offers a continuous piece of commentary; Mühlhausen (fol. 178r) transmits the same commentary, but divided into several parts: the first part is written in the right margin, the second part in the margin below, the third part again in the right margin, and the rest of the text again in the margin below. ${ }^{19}$ It is important to notice that this comment deals with one topic, but the continuous commentary is interrupted and is moved several times in Mühlhausen. The second example of a change in order is the following: in the left margin of Wolfenbüttel (fol. 97v), there are three consecutive pieces of comments: A (“In ista particula tertia...”), B (“Hic ponit 4m dispositionem ...”), and C ("Sciendum hortiga est...”). In Mühlhausen (fol. 181r), in contrast, the order of the comments is different: A and C follow each other and are written as one note; B is written in the other margin. For the two examples, there is no logical explanation why Mühlhausen would copy the content in such a different manner and in such a different order than its source manuscript, nor a reason why the postils would be distributed in such a different fashion. This therefore leaves open the possibility that Mühlhausen is not a direct copy from Wolfenbüttel, but copied from another common source. This would also be in alignment with what we have seen in the previous section on the main text of the manuscript.

\section{Origin of the similar manuscripts}

Although having several copies with the same marginal notes is quite exceptional in the tradition of the Latin Physiognomonica, it does happen in the tradition of other Aristotelian

\footnotetext{
${ }^{19}$ When discussing the glosses in the Latin De plantis, French discusses the format in which these notes were written. He mentions that "the student wherever possible began his postil in one of the vertical columns ruled in the margin by the original scribe, on the same ruled horizontal line of the text as the textual lemma. If the postil was long and threatened to over-run the location of the next postil, the student continued his line of writing over into the next vertical column and filled another rectangular space." Roger French, "Teaching Aristotle in the Medieval English Universities: De plantis and the Physical Glossa ordinaria," Physis. Rivista internazionale di storia della scienza 34 (1997): 225-296 at 233. This is, however, not the case for the Mühlhausen manuscript. The comments were not divided in order to be next to their corresponding textual lemma, because they can all be found at the bottom of the folio without interaction with the main text.
} 
treatises. One example is the so-called Oxford gloss, or glossa anglicana, a corpus of scholarly glosses that originated in the teaching activities at the Arts Faculty of the university of Oxford. In several manuscripts containing the translatio vetus of the Aristotelian Physica, De plantis and De sensu et sensato, scholars have discovered that similar (although not identical) glosses can be found, and that they probably depend directly or indirectly on a common source. Those manuscripts containing the similar glosses can be connected to the teaching in Oxford, and from there they influenced natural philosophical treatises cross Europe. ${ }^{20}$ In the case of the Physiognomonica, we cannot speak of a corpus of glosses, since only two manuscripts display these similar glosses. However, the possibility or hypothesis that the marginal notes are based on lectures - within or outside the university milieu - cannot be validated, nor refuted. Although there is no evidence that the Physiognomonica was part of the official curriculum, it certainly circulated among scholars at the University of Paris. ${ }^{21}$ Moreover, it is clear from the Wolfenbüttel manuscript that the marginal annotations are similar to an expositio commentary with an introduction and a text that is divided into several lectiones. However, although many medieval commentaries have their origin in the university tradition, they can also be written outside the institutional context. ${ }^{22}$

Notwithstanding the great similarities between the Mühlhausen and Wolfenbüttel manuscripts, the origin of their common source remains unclear. The manuscript of Wolfenbüttel has been

\footnotetext{
${ }^{20}$ For a discussion and overview of the Oxford gloss, see Charles Burnett and Andrew Mendelsohn, "Aristotle and Averroes on Method in the Middle Ages and Renaissance: the 'Oxford Gloss' to the Physics and Pietro d'Afeltro's Expositio Proemii Averroys," in Method and Order in Renaissance Philosophy of Nature. The Aristotle Commentary Tradition, ed. Daniel A. Di Liscia et al. (Aldershot, 1997), 53-111; Griet Galle, "Edition and Discussion of the Oxford Gloss on De sensu 1," Archives d'Histoire Doctrinale et Littéraire du Moyen Age 75 (2008): 197-281; Emmanuelle Kuhry, "The Compilatio de libris naturalibus Aristotelis (Compendium philosophie): Evidence for the Early Reception of the Glossa anglicana and of Adam of Buckfield's Commentaries," Recherches de Théologie et Philosophie Médiévales 86/2 (2019): 283-313. For a discussion on the origin and format of these notes, see French, "Teaching," 233-238.

${ }^{21}$ Devriese, "Physiognomy in Context," 137. The University of Bologna is the first university that mentions the Physiognomonica in its curriculum, see Agrimi, Ingeniosa, 109.

${ }^{22}$ Olga Weijers, "La structure des commentaires philosophiques à la Faculté des arts: quelques observations," in Il commento filosofico nell'Occidente latino (secoli XIII-XV), ed. Gianfranco Fioravanti, Claudio Leonardi, and Stefano Perfetti (Turnhout, 2002), 17-41 at 37.
} 
written in 1419 and 1420 and is now preserved in the Herzog August Bibliothek. It belongs to the so-called Augusteische Sammlung, which is the book collection of Duke August of Brunswich-Lüneburg (1579-1666). ${ }^{23}$ Although the catalogue does not mention the origin of the manuscript, it offers several clues that could point to a German origin of the manuscript, and more specifically the region of Braunschweig, Eisenbüttel, Magdeburg and Leipzig. ${ }^{24}$ First, the explicit of the seventh treatise in the manuscript mentions the city of Leipzig: "Explicit textus declarans quoddam instrumentum astronomicum dictum horalumen in anno Domini 1420 declaratum Lypcz per dies caniculares" (fol. 71v). Secondly, several German names and places are mentioned throughout the manuscript: "Johannes Braxator civis in Madgeborch" (fol. 36r), "Hans von der Helle unde sin husfruwe" (fol. 37r), and "Ludolfus Wideman" and "Hans von Eysenbüttel" (fol. 150v). ${ }^{25}$

The fourth fascicle of the manuscript of Mühlhausen, on the other hand, was written around 1420, most likely in Erfurt. It was originally preserved in the Dominican monastery of Mühlhausen and was probably brought there by Hermann von Thalheim, who had studied in Erfurt and Cologne. ${ }^{26}$

The fact that there might be a geographical and temporal connection between the two manuscripts, both originating in central Germany around 1419-1420, could suggest that the interlinear and marginal annotations present in both manuscripts originated in the same area. It is possible that these glosses were transmitted via the Dominican studia. These study-houses of the religious order were responsible for the learning of the friars in liberal arts and theology, and were more widely distributed than the medieval universities. There are studia in, among

\footnotetext{
${ }^{23}$ Bernhard Fabian, Handbuch der historischen Buchbestände in Deutschland, digitized by Günter Kükenshöner (Hildesheim, 2003), accessed May 3, 2021, https://fabian.sub.unigoettingen.de/fabian?Herzog_August_Bibliothek.

${ }^{24}$ I thank Matthias Eifler for making me aware of this. For the catalogue, see von Heinemann, Augusteischen Handschriften, 225-226.

${ }^{25}$ It is, however, not clear when to situate these name entries.

${ }^{26}$ For information on the Dominican monastery of Mühlhausen, see the bibliography in the description of manuscript Mühlhausen, Stadtarchiv 60/34 at http://www.manuscripta-mediaevalia.de/dokumente/html/obj 31628424, accessed May 3, 2021.
} 
others, Erfurt, Leipzig and Magdeburg, that could be responsible for the similarities between the two manuscripts under discussion. ${ }^{27}$ Although we do not have a lot of material evidence, the hypothesis would imply an interest in physiognomy in a religious context and could shed more light on the dissemination of the Latin translation of the pseudo-Aristotelian Physiognomonica outside the academic university milieu. ${ }^{28}$

\section{Conclusion}

This short article discussed the newly discovered manuscript of Mühlhausen, Stadtarchiv, 60/13. The examination of the Latin translation of the Physiognomonica contained in this manuscript has demonstrated that the text belongs to a large group of manuscripts with a good quality of the text, but with no value for the reconstruction and edition of the original translation made by Bartholomew of Messina. The discussion of the marginal and interlinear annotations has shown that the manuscript bears great similarities with another manuscript of the Physiognomonica tradition, i.e. manuscript Wolfenbüttel, Herzog August Bibliothek, Cod. Guelf. 17.21 Aug. $4^{\circ}$. The existence of two manuscripts with the same annotations is very rare in the tradition of the Physiognomonica, and sheds some light on the dissemination of commentaries and glosses on this pseudo-Aristotelian treatise in a religious environment. Although the issue of the origin of these notes leaves us with more questions than answers,

\footnotetext{
${ }^{27}$ Michèle Mulchahey, "First the Bow is Bent in Study”. Dominican Education before 1350 (Toronto, 1998), 132133; on the teaching of Arts and natural philosophy, see ibid., 238-277. Helmut G. Walther, "Ordensstudium und theologische Profilbildung. Die Studia generalia in Erfurt und Paris an der Wende vom 13. zum 14. Jahrhundert," in Meister Eckhart in Erfurt, ed. Andreas Speer and Lydia Wegener (Berlin, 2005), 75-94 at 91. For a discussion of the teaching of the different mendicant and monastic religious orders in studia, as well as the medieval scholastic literature they produced, see Kent Emery Jr., William J. Courtenay, and Stephen M. Metzger, Philosophy and Theology in the 'Studia' of the Religious Orders and at Papal and Royal Courts (Turnhout, 2012) and more specifically the contribution of Alessandro Palazzo, "Philosophy and Theology in the German Dominican scholae in the Late Middle Ages: The Cases of Ulrich of Strasbourg and Berthold of Wimpfen," 75-105.

${ }^{28}$ Ziegler has already demonstrated that religious communities were using physiognomic ideas in their biblical treatises. They did not focus on the potential problems of physiognomy for Christianity, but rather viewed it as a tool to assess the character and protect the soul. Joseph Ziegler, "Text and Context: On the Rise of Physiognomic Thought in the Later Middle Ages," in De Sion Exibit Lex et Verbum Domini de Hierusalem: Essays on Medieval Law, Liturgy and Literature in Honour of Amnon Linder, ed. Hen Yitzhak (Turnhout, 2001), 159-182 at 161-176.
} 
having two copies of the same comments might indicate a wider reception of the (possibly early fifteenth-century) commentary or text-gloss that was at the basis of the two manuscripts. 